\title{
Analysis of volcanic threat from Nisyros Island, Greece, with implications for aviation and population exposure
}

\author{
H. S. Kinvig ${ }^{1, *}$, A. Winson ${ }^{1, *}$, and J. Gottsmann ${ }^{1}$ \\ ${ }^{1}$ Department of Earth Sciences, University of Bristol, Wills Memorial Building, Queen's Road, Bristol, BS8 1RJ, UK \\ *these authors contributed equally to this work
}

Received: 27 January 2010 - Revised: 19 May 2010 - Accepted: 21 May 2010 - Published: 7 June 2010

\begin{abstract}
Nisyros island in the South Aegean volcanic arc, Greece, is a Quaternary composite volcano with a $3.8 \mathrm{~km}$ wide caldera that in 1996 entered a volcano-seismic crisis, which heralded the islands' return to a state of unrest. The caldera has been the locus of at least thirteen phreatic eruptions in historical times, the most recent in 1888, and the system is still presently affected by considerable hydrothermal activity. Although the recent unrest waned off without eruption, there are still open questions relating to the current threat of volcanic activity from the island. Here, we perform a detailed and systematic assessment of the volcanic threat of Nisyros using a threat analysis protocol established as part of the USGS National Volcano Early Warning System (NVEWS). The evaluation involves a methodical assessment of fifteen hazard and exposure factors, and is based on a score system, whereby the higher the score, the higher the threat is. Uncertainty in assessment criteria are expressed by allowing for a conservative and an extreme score for each factor. We draw our analysis from published data as well as from results of our research on Nisyros over the past years. Our analysis yields a conservative threat score of 163 and an extreme score of 262. The most adverse exposure factors include significant scores relating to aviation and population exposure to volcanic hazards from Nisyros. When looked at in comparison to US volcanoes both scores place Nisyros in the "Very High Threat (VHT)" category, grouping it with volcanoes such as Redoubt, Mount Ranier and Crater Lake. We identify a short-fall in recommended surveillance efforts for VHT volcanoes given existing monitoring capabilities on the island. We discuss potential pitfalls of applying the NVEWS scheme to Nisyros and suggest potential adapta-
\end{abstract}

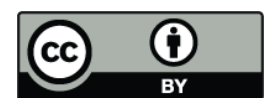

Correspondence to: J. Gottsmann (j.gottsmann@bristol.ac.uk) tion of analysis scheme to match industrial and societal conditions in Europe. At the same time, our findings indicate that that volcanic threat posed by Nisyros volcano may currently be underestimated.

\section{Introduction}

Nisyros Island is an $8 \mathrm{~km}$ wide Quaternary composite volcano, which constitutes the eastern most edge of the South Aegean volcanic island arc, Greece (Fig. 1). The most conspicuous geologic feature of Nisyros is its $3.8 \mathrm{~km}$ wide caldera, which is thought to have formed during a large explosive rhyolitic eruption $\sim 45 \mathrm{ka}$ before present (Vougioukalakis, 1998), and has since been partially refilled by dacitic domes (Figs. 1 and 2). Historically, there have been 13 phreatic eruptions in the caldera, most recently during 1871-1873 and in 1888 (Marini et al., 1993). More recently, in 1996-1998, Nisyros experienced a volcano-seismic crisis, accompanied by ground uplift of more than $10 \mathrm{~cm}$, indicating a period of unrest (Papadopoulos et al., 1998). Nisyros volcano presents an opportunity to study the threat posed by a relatively small volcano situated in an arc-island setting in both Europe and a region of significant seasonal population exposure. The island is easily accessible and despite only a small stable population, Nisyros and surrounding areas are exposed to a large transient tourist population.

There have been several notable attempts to develop volcanic hazard and risk ranking systems with the purpose of determining, which volcanoes are most dangerous and warrant further study and monitoring (Ewert, 2007). These systems have been applied in the US (Bailey and Survey, 1983; Ewert, 2005), Papua New Guinea (Lowenstein and Talai, 1984) and globally (Yokoyama, 1984) with varying success. 

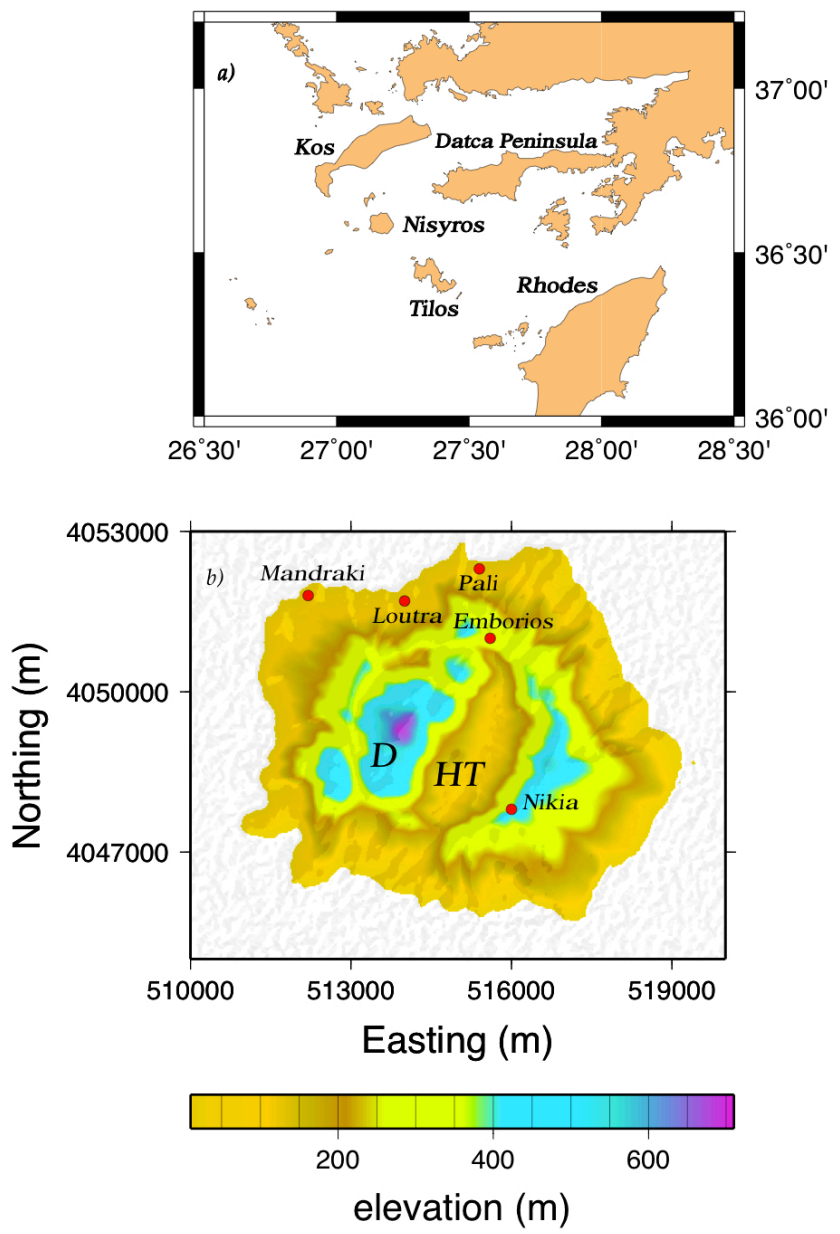

Fig. 1. (a) Map of the Dodecanese region of the Aegean indicating location of Nisyros. For a regional context see Fig. 5. (b) Colorcoded digital elevation model of Nisyros from SRTM $90 \mathrm{~m}$ data indicating location of main population centres of the island, the hydrothermally active caldera floor (HT) and the post-caldera domes (D).

Bailey and Survey (1983) were the first to attempt to develop a general assessment of the potential for future eruptions in the United States. This was done in response to heightened public awareness of the vulnerability of populations to geological hazards following the 1980 eruption of Mount St Helens. The system groups volcanoes based on their most recent eruption and the eruption periodicities. This assessment is helpful in showing similarities between volcanoes but does not involve enough detailed analysis to provide a quantifiable threat score.

Lowenstein and Talai (1984) developed a system to rank volcanoes in Papua New Guinea by using a "danger score". This system treated active and dormant volcanoes differently, where an active volcano was defined as one that had erupted in historical times (Lowenstein and Talai, 1984). Dormant volcanoes were those with particularly youthful

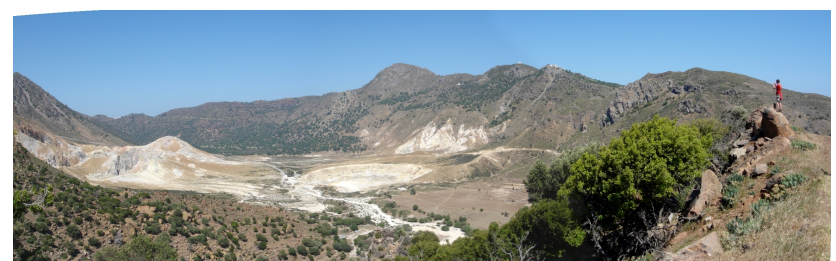

Fig. 2. Panoramic image towards the NE showing the caldera floor (the Laki plain) and the hydrothermally active area as well as the exposed caldera wall. The phreatic Stefanos crater is located in the centre together with other phreatic craters and domes to its left. Post-caldera dacitic domes mark the left border of the image. The width of view is about $3 \mathrm{~km}$.

morphological features, active or recently active fumaroles and indigenous stories or legends of eruptions (Lowenstein and Talai, 1984). The system included factors based on geological features, historically recorded hazardous phenomena, and present features. The hazard factors were then summed with the population data to generate a potential hazard rating.

Yokoyama et al. (1984) developed a system to evaluate all the volcanoes in the world as part of a UNESCO/UNEP study. The goal of the study was to review the status of the existing volcano - monitoring capabilities of the countries in the world and to prioritise the resources for mitigating volcanic hazards worldwide. The assessment was carried out on all the active volcanoes in the world. In this case "active volcanoes" were classified as volcanoes that have erupted in historical times or that still retain some fumarolic fields. This scheme involved using ten hazard factors and seven risk factors that are scored; these results are then summed to identify high risk volcanoes. Volcanoes receiving a total score of 10 or greater were "arbitrarily" identified as "high risk".

NVEWS, the system that we will use to generate a threat score for Nisyros in this paper, was built on the previous works mentioned above. It is the most comprehensive scheme developed to date, as it incorporates both volcanic hazard and exposure factors in greater detail then any of the previous three. Most importantly, the evaluation is targeted towards the assessment of threat and therefore deviates significantly from the aforementioned schemes.

\section{NVEWS threat scheme}

The National Volcano Early Warning System (NVEWS) (Ewert, 2007) is intended to assess the threat posed by volcanoes in the US by devising an analysis scheme that involves the assessment of several factors. Broadly, the factors can be divided into those associated with a hazard (i.e. the dangerous/destructive natural phenomena produced by a volcano) or an exposure to assets (human and financial) potentially affected by the realisation of the hazard. The scheme works by assigning values to a series of questions, allowing a threat score to be generated for the volcano. There are 
15 hazard factors including seismicity within $20 \mathrm{~km}$ of a volcano, ground deformation in response to magma intrusion and gross changes to existing hydrothermal systems and degassing. The exposure factors include an assessment of the population within a $30 \mathrm{~km}$ radius of the active volcanic centre, the local aviation exposure and an assessment of local power infrastructure. The goal of this system is to create a threat ranking of volcanoes so that an appropriate level of monitoring can be assessed (Ewert et al., 2005). The principle of the NVEWS scheme is that the degree and type of early warning monitoring at a particular volcano should be appropriate to the threat it poses. To achieve optimum volcano monitoring it is suggested by NVEWS to use an integrated combination of approaches such as ground-based, airborne and remote sensing; with the rational that data from adequately-monitored volcanoes enable scientists to assess ensuing scenarios before they manifest, in contrast to activity that remains unforeseen due to a lack of data. Here we apply the scheme to Nisyros to inform on the current threat level in the context of the NVEWS ranking.

In this paper we will be using the terms "Risk", "Threat", and "Vulnerability" as defined by the International Charter. "Threat" is defined as the frequency of potentially adverse events, and in this case we can define threat as the physical products of the volcano such gas emissions or pyroclastic flows. "Vulnerability" is the likelihood of success of a particular threat category against a particular organisation or individual and can usually be expressed as a "percentage of likelihood". The "Risk" is defined as a product of the threat, vulnerability and the total cost of the impact of a particular threat, experienced by a vulnerable target. It is important to note that in the context of this paper we will be generating a threat assessment and not a risk assessment. The latter is beyond the scope of this work as no attempt has been made to quantify potential losses accompanying the realisation of threats from Nisyros.

\section{A brief summary of the geological evolution of Nisy- ros and the recent episode of volcano unrest}

The island of Nisyros is part of the Southern Aegean Active Volcanic Arc in Greece. This region is the site of active plate convergence with calc-alkaline volcanism along the arc initiating in the Tertiary as a result of northwards subduction of the African plate beneath the Aeagean-Anatolian plates (Innocenti, 1981; Papazachos et al., 2005). Other important volcanoes in this arc chain include Santorini, Milos, Poros and Methana. Nisyros hosts a $3.8 \mathrm{~km}$ wide caldera at its centre (Fig. 2), and is itself considered to have developed on the inferred edge of the larger submarine caldera created by the region's largest eruption - that of the Kos Plateau Tuff (KPT) 161 ka (Smith et al., 1996; Allen, 2001; Pe-Piper and Piper, 2005). Nisyros began its evolution with the submarine build up of basaltic-andesitic pillow lavas and hyalo- clastites and eventually emerged above sea level allowing the development of a subaerial edifice. The inception of volcanism is poorly constrained, but deposits attributed to the KPT eruption are found at the top of the submarine lava sequence (Keller, 1971; Volentik et al., 2005) indicating that the onset of subaerial volcanism was younger than $161 \mathrm{ka}$ (Smith et al., 1996). Cone building continued with alternating episodes of explosive and more effusive activity gradually generating a complex strato-volcano composed of tephra and lavas, with eruptive products ranging from basaltic-andesites to rhyolites (e.g. Volentik et al., 2005). Nisyros' central caldera has been attributed to the most recent of this explosive activity, associated with two large Plinian eruptions (Lower Pumice and Upper Pumice) (Limburg and Varekamp, 1991; Vougioukalakis, 1998; Hardimann, 1999; Volentik et al., 2005).

The timing of volcanic activity on Nisyros is poorly constrained despite numerous attempts at age dating by several techniques. Estimated ages for the Lower and Upper Pumice deposits associated with caldera formation are spread over a large range between $110 \pm 40 \mathrm{ka}$ (Barberi et al., 1988, by fission tracking in volcanic glass) and $24 \mathrm{ka}$ (Vinci, 1983, 1985 by the extrapolation of sedimentation rates), but some consistency is shown for an age of $\sim 45 \mathrm{ka}$ with ${ }^{14} \mathrm{C}$ dating of charcoal found in Upper Pumice surges yielding $\geq 44 \mathrm{ka}$ (Limburg and Varekamp, 1991), and correlation of a widespread tephra marker found across the north Aegean with glass from the Lower and Upper Pumice, dated to ca. $46 \pm 6 \mathrm{ka}$ (Margari et al., 2007; Aksu et al., 2008; Pyle and Margari, 2009).

Post-caldera volcanism is represented by the extrusion and growth of NE-SW aligned rhyo-dacitic lava domes which today fill the western half of the caldera and spill over its south-western rim (Seymour and Vlassopoulos, 1989; Limburg and Varekamp, 1991; Volentik et al., 2005). The domes denote the most recent magmatic eruptions on Nisyros, but there has since been significant hydrothermal activity below the caldera floor and there have been thirteen phreatic eruptions in historic times, most recently in 1871-1873 and 1888 (Marini et al., 1993; Caliro et al., 2005). These phreatic eruptions were characterised by the formation of phreatic craters, discharge of fumarolic fluids, $\mathrm{H}_{2} \mathrm{~S}$ and associated earthquakes (Marini et al., 1993). Today Nisyros is a site of intense hydrothermal activity with surface expressions covering an area of approximately $0.9 \mathrm{~km}^{2}$ in the southern part of the caldera floor; including active fumaroles, boiling mud pools, diffuse degassing of $\mathrm{CO}_{2}$ and additionally coastal hot springs (Figs. 2 and 3).

In 1996-1998, Nisyros showed signs of unrest with a seismic crisis accompanied by intense ground deformation and increased activity and geochemical variations of the island's fumaroles (Papadopoulos et al., 1998; Sachpazi et al., 2002; Lagios et al., 2005; Caliro et al., 2005). During this period, more than 1600 earthquakes occurred (Papadopoulos et al., 1998). Sachpazi et al. (2002) suggest that these events were compatible with the intrusion of a magmatic body at shallow depth within the crust of the Nisyros region, rather than 


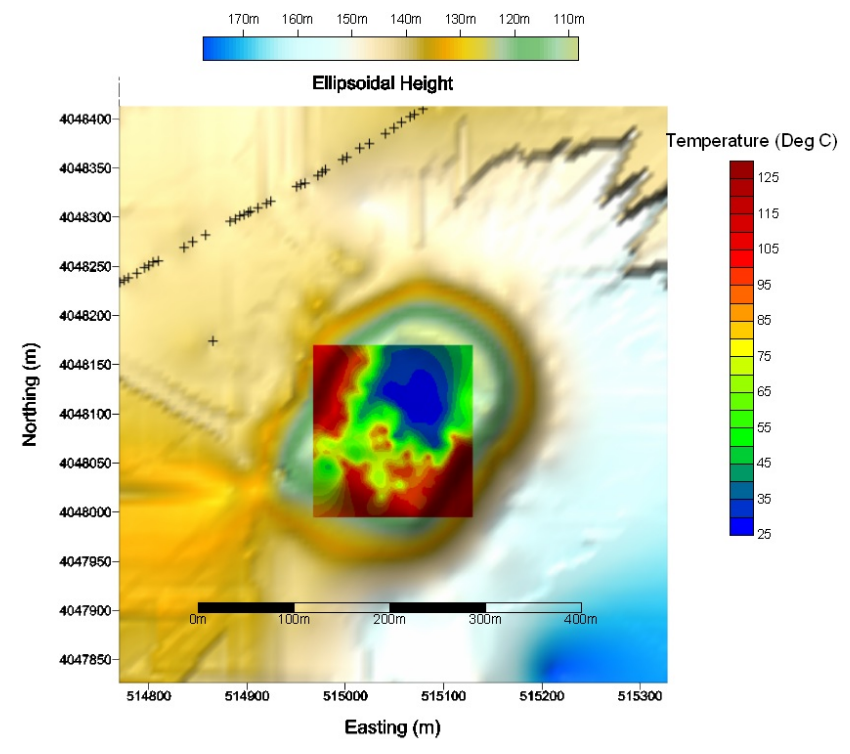

Fig. 3. Plot of surface temperature data recorded at $20 \mathrm{~cm}$ depth inside Stefanos crater in May 2008. The data were obtained using a K-type thermocouple and data logger over a grid of measurement points at $5 \mathrm{~m}$ spacing. The data are georeferenced and superimposed over a high-precision digital elevation model obtained from kinematic GPS surveying in May 2008.

being attributed to regional tectonic motions. Ground uplift, with a maximum amplitude of $14 \mathrm{~cm}$, was recorded by InSAR and GNSS (Lagios et al., 2005) during the crisis, this was followed by ground subsidence from 1999 onwards.

\section{Volcanic threat analysis}

\subsection{NVEWS hazard factors}

The NVEWS assessment presents a list of volcanic hazard criteria, each of which receives a score of one if manifested by the volcano within the Holocene. In the absence of evidence for realisation of a hazard the volcano scores no point. One of the major uncertainties in assessing whether or not a hazard occurred in the Holocene is the lack of unambiguous results from geochronology. To account for this uncertainty two scores have been generated for Nisyros: an extreme score (ES) which assumes activity occurred within the Holocene, and a conservative score (CS) which assumes activity was earlier.

\subsubsection{Volcano type $(\mathrm{CS}=1 / \mathrm{ES}=1)$}

The NVEWS scheme uses the Smithsonian's Global Volcanism Program (GVP) reference file to establish a specific volcano's coordinates, type, and eruption frequency and eruption magnitude. Type 0 volcanoes in this scheme include; cinder cones, basaltic volcanic fields, shields, tuff rings and fissure vents. Type 1 volcanoes are generally more explosive, for example, stratovolcanoes, lava domes, complex volcanoes, maars and calderas. In this category the scores simply represent less dangerous versus more dangerous volcanoes, though we acknowledge that Type 0 volcanoes can still represent significant volcanic hazards. The GVP identifies the volcano type for Nisyros as a stratovolcano. This characterisation in addition to the presence of a caldera depression on Nisyros, yields a score of 1 for Nisyros.

\subsubsection{Maximum VEI $(\mathrm{CS}=1 / \mathrm{ES}=1)$}

The VEI is a general indicator of the explosive character of an eruption (Newhall and Self, 1982). In the NVEWS scheme an eruption with a VEI of 3-4 is awarded 1 point, VEI 5-6's are awarded 2 points and VEI 7-8's are given 3 points. If there is no eruption magnitude reported in the literature then the score is determined by the volcano type. Type 0 volcanoes receive a score of 0 and Type 1 volcanoes receive a score of 1 . Although there has been no formal VEI designated for Nisyros, Limburg and Varekamp (1991) estimated that the DRE for the caldera forming eruption was between $2-3 \mathrm{~km}^{3}$ and the calculated plume height was 15 $20 \mathrm{~km}$ high. These calculations were made by analysis of two pumice deposits on the island which are associated with the formation of the summit caldera. These parameters indicate that the Plinian eruptions on Nisyros can be classified as VEI 4 (Newhall and Self, 1982). The score for this category is therefore 1 . Given the small size of the island, and thus proximal location beneath a Plinian column, standard granulometric techniques to calculate plume heights and thus a VEI may be inappropriate to apply to Nisyros. However, we note here that a score of 1 would also be achieved by the criteria of volcano type. We are therefore confident that the resultant score is a minimum of 1 .

\subsubsection{Explosive activity and major explosive activity $(\mathrm{CS}=0 / \mathrm{ES}=0 ; \mathrm{CS}=0 / \mathrm{ES}=1)$}

These two factors emphasise systems that are active and explosive whilst de-emphasising those that may have had major explosive activity at some point in the Holocene, but have changed their eruptive styles or quietened down since. The eruption activity must be VEI 3 or above and have occurred within the last 500 years to score, therefore Nisyros was given a score of 0 for this category. To score in the major explosive activity category there must have been activity of a VEI 4 or above within the last 5000 years. As there is a lack of information for this category on Nisyros, the extreme score is given as 1 and the conservative score is given as 0 .

\subsubsection{Eruption recurrence $(\mathrm{CS}=1 / \mathrm{ES}=1)$}

This factor should reflect the average time between eruptions, irrespective of the explosivity of these eruptions. If the eruption interval is between 1 and 99 years then the system 
scores 4 , if the interval is between 100 and 1000 years the score is 3 , a $1000-5000$ year interval scores 2 . If the eruption recurrence is 5000-10000 years or if there is no Holocene eruption but the system is a large Pleistocene silicic caldera system and has erupted in the last 100000 years, then the score is 1 . The system should also be demonstrating seismic, deformation and fumarolic unrest. If there is no known Holocene eruption then the score is 0 . The eruption history at Nisyros is poorly constrained so the eruption interval is unknown. Due to the uncertainties in the Nisyros data for the eruption recurrence the score was given as 1 . This is mainly awarded because Nisyros is a silicic system and demonstrates seismic, deformation and fumarolic activity (Gottsmann et al., 2007; Papadopoulos et al., 1998; Caliro et al., 2005).

\subsubsection{Holocene pyroclastic flows $(\mathrm{CS}=0 / \mathrm{ES}=1)$}

Pyroclastic flows are very destructive and represent the most dangerous of volcanic hazards. If the system has produced pyroclastic flows in the past then it is considered to be capable of producing them again and thus the presence of their deposits would lead to a score of 1 . The rhyolitic Lower and Upper Pumice units on Nisyros include extensive pyroclastic flow deposits which are attributed to the island's last major explosive episode. These deposits extend across the island into now populated areas; however, the ages of these flows are not well constrained and so cannot be confirmed to have occurred within the Holocene. The conservative score for this section is therefore 0 , whilst the extreme score is 1 .

\subsubsection{Holocene lava flows $(\mathrm{CS}=\mathbf{0} / \mathrm{ES}=1)$}

This factor applies to volcanoes that have produced lava flows that have travelled from the eruption site, beyond the volcano and have reached populated areas. There are many lava flows on Nisyros, including those which extend into populated areas (after-which they are then named), however the ages of these flows is once again poorly constrained and so cannot be attributed with confidence to the Holocene. The largest and most recent lava extrusions are represented by the dacitic post-caldera domes which have inundated the western half of the caldera and extend beyond its south-western wall (these are considered to be Holocene products by Tibaldi et al., 2008). Another voluminous lava flow is the rhyolitic Nikia Lava, which has a maximum thickness of $150 \mathrm{~m}$ and covers most of the south-eastern part of the island including the old port of Avlaki, and on which the town of Nikia is built (e.g. Volentik et al., 2005). Due to the unknown age of these lava flows, the conservative score for this section is 0 and the extreme score is 1 .

\subsubsection{Holocene lahars $(\mathrm{CS}=0 / \mathrm{ES}=0)$}

This factor is similar to the lava flow category and applies to volcanoes where large lahars have travelled from the eruption site, beyond the volcano and have reached populated areas.
As with the pyroclastic flow category, if lahars have reached populated areas in the past then it is deemed likely that this could happen again. There are lahar deposits on Nisyros, including in the caldera floor surrounding the phreatic crater pits, within the vicinity of which there are small farms. However, we found no evidence for lahar deposits inundating currently permanently populated areas and therefore the score is 0 .

\subsubsection{Holocene tsunami $(\mathrm{CS}=0 / \mathrm{ES}=1)$}

If there have been tsunamis generated by sector collapse but sector collapse is no longer an issue then the score for this category is 0 . If, however there have been tsunamis caused by factors that are still present then the score is given as 1 (Ewert et al., 2005). For example, if there is evidence that there is potential for another sector collapse, explosive eruptions into water or pyroclastic flows that could reach the sea. Whilst there is no geological evidence of Holocene tsunamis on Nisyros (and therefore the conservative score is 0 ), sector collapses have been suggested to have occurred in the north-west and south-east of the island (Volentik et al., 2005; Tibaldi et al., 2008). On Nisyros a sector collapse would inevitably deposit material into the sea, which could easily generate volcanogenic tsunamis. Pyroclastic flow deposits have also reached the coast in the past, and would likely do so again in the event of a similar size eruption in the future. As this is the case the extreme score for this section is 1 .

\subsubsection{Hydrothermal explosion potential $(\mathrm{CS}=1 / \mathrm{ES}=1)$}

This factor identifies if the system has evidence of significant Holocene phreatic explosive activity. A volcanic system can also score in this category if there are thermal features present that are significant enough to have the potential for explosive activity. Nisyros has a highly active hydrothermal system (Fig. 3) and hosts a high enthalpy geothermal reservoir, with temperatures $>300^{\circ} \mathrm{C}$ at $1700 \mathrm{~m}$ depth (Caliro et al., 2005). At least thirteen phreatic eruptions have occurred in historic times, generating phreatic craters and associated hot mud flows (e.g. Marini et al., 1993; Caliro et al., 2005). The last major phreatic eruptions occurred in 1888, forming the Lofos Crater and went on for several days. Multiparameter investigations indicate anomalous geophysical signatures associated with magma degassing (Caliro et al., 2005; Gottsmann et al., 2005, 2007) and an increase in hydrothermal activity during remote seismic triggering by two global earthquakes in May 2006 (Gottsmann et al., 2007). These observations demonstrate the susceptibility of the hydrothermal system to abruptly changing conditions in its physical characteristics. Sudden catastrophic discharge of hot mud and rocks during phreatic eruptions poses therefore a significant threat and a score of 1 is propagated for this category. 


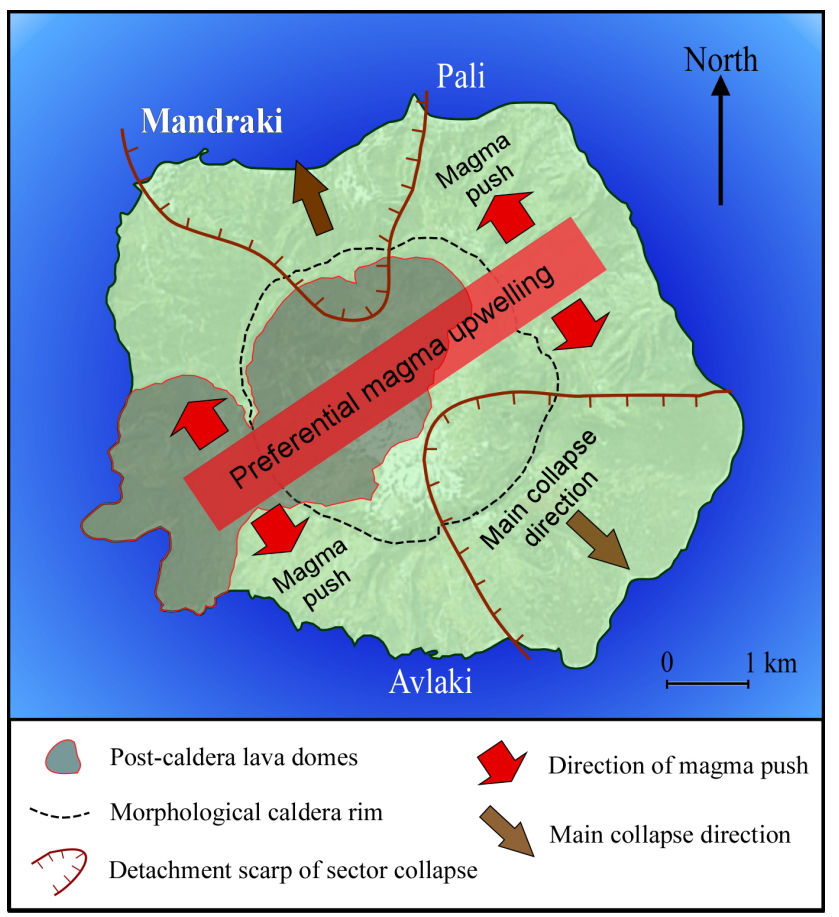

Fig. 4. Sketch illustrating the geometrical relationships between the preferential NE-SW zone of magma injection across Nisyros island and the location and failure direction of two sector collapses (modified after Tibaldi et al., 2008). The post-caldera domes are also marked to illustrate their correspondence with a NE-SW trending magma injection. The collapse towards the NW is documented by Vanderkluysen et al. (2005) and the collapse towards the SE is documented by Tibaldi et al. (2008). Repeated magma injections are suggested by Tibaldi et al. (2008) to generate a lateral magma push directed perpendicular to the NE-SW zone, which in turn causes destabilization of the volcanic edifice and thus may explain the orientation of these two sector collapses.

\subsubsection{Sector collapse potential $(\mathrm{CS}=1 / \mathrm{ES}=1)$}

This factor is limited to stratovolcanoes and large oceanic shield volcanoes. "Generally if a volcano is more than ca. $1000 \mathrm{~m}$ high with active fumaroles or large altered areas and/or has a permanent snow and ice cover, and appears to be steep sided, then it scored positively" (Ewert, 2007). Volcanoes which have a history of sector collapse where the edifice has been re-built also receive a score of 1 . Two sector collapses have been inferred to have occurred on Nisyros (Volentik et al., 2005; Principe and Marini, 2005; Tibaldi et al., 2008) and their proposed collapse scarps have since been in-filled and the edifice rebuilt - giving Nisyros a score of 1. Figure 4 shows the suggested detachment scars for the proposed sector collapses and their possible relationship with magmatic intrusions controlled by NE-SW aligned regional tectonic structures. If such a tectonic structure is still active in controlling the location of magmatic injections, then a similar destabilisation of the current edifice could poten- tially produce future sector collapses. The possibility of a future sector collapse on Nisyros is also increased by the presence of an active hydrothermal system, due to interactions between hydrothermal fluids and the volcanic edifice. These act to both induce rock dissolution and mineral alteration, generating weaker clay material which essentially lubricates the collapse, while earthquakes can act as physical triggers of collapse (Lopez and Williams, 1993). The past collapses on Nisyros combined with the presence of an active hydrothermal system and the existence of large domes (with elevations of almost $700 \mathrm{~m}$ a.s.l. rising ca. $550 \mathrm{~m}$ above the caldera floor), which could be prone to collapse, lead to a score of 1 for this category.

\subsubsection{Primary lahar source $(\mathrm{CS}=0 / \mathrm{ES}=0)$}

As many volcanoes have not been mapped sufficiently to determine whether or not they have had lahars in the past, this factor addresses possible sources for future lahars. As water is needed to mobilise soft sediments this factor assesses whether or not there is a water source in the form of either a crater lake or permanent snow cover that could potentially generate a lahar in the event of a volcanic eruption. A volcano will receive a score for this category if there is a source of permanent water/ice on the edifice with a volume of $10^{6} \mathrm{~m}^{3}$. If this criterion is met then the score for this category is 1 . There is no permanent water source on Nisyros, so the score is 0 . Heavy rainfall during rainy seasons can also trigger lahars, however the current climate on Nisyros does not demonstrate such episodic wet periods. It is however worth mentioning that the historical phreatic eruptions on Nisyros generated hot mudflows which outpoured from around the explosion pits (Marini et al., 1993). Whilst not considered a permanent water supply in the true sense, and that of the NVEWS scheme, the geothermal fluids associated with hydrothermal eruptions can generate minor lahars.

\subsubsection{Historical unrest factors}

In the NVEWS scheme "unrest" is taken to mean "abnormal geophysical activity since the last eruption" (Ewert et al., 2005). The "unrest factors" are relevant if unrest has occurred since the last eruption and is ongoing. This scheme considers that fumarolic activity and the presence of magmatic gas isotopes in cold springs are the most persistent representations of unrest. Seismic and deformation unrest are also used but these factors generally (though not always) require instrumental monitoring for detection.

\subsubsection{Observed seismic unrest $(\mathrm{CS}=1 / \mathrm{ES}=1)$}

To score in this category there must be seismic activity within $20 \mathrm{~km}$ of the volcano. Earthquakes that occur on regional faults and are not directly related to the volcanic system are excluded. There was a volcano-seismic crisis on Nisyros between 1996 and 1998, with over 1600 earthquakes recorded, 
reaching up to magnitude $M_{\mathrm{S}} 5.3$ on 27 August 1997 (Papadopoulos et al., 1998). The seismicity was attributed to the shallow intrusion of a magma body within the crust of the Nisyros region (Sachpazi et al., 2002) and it was concluded that the Nisyros caldera had entered a period of unrest, with long-lasting earthquake activity (Papadopoulos et al., 1998). Nisyros scores 1 for this category.

\subsubsection{Observed ground deformation $(\mathrm{CS}=1 / \mathrm{ES}=1)$}

This category is meant to highlight systems that are deforming due to the intrusion of magma or that exhibit major changes in their hydrothermal system. This factor does not include systems that are solely subsiding. Nisyros showed significant ground deformation between 1996 and 1998 (Sachpazi et al., 2002). Uplift of $14 \mathrm{~cm}$ was recorded, which was partly interpreted as the elastic response of the shallow volcanic edifice to the inflation of a magma chamber. A ground rupture $600 \mathrm{~m}$ in length formed along the caldera floor between 2001 and 2002 (Lagios et al., 2005). We derive a score of 1 for this category.

\subsubsection{Observed fumarolic or magmatic degassing $(\mathrm{CS}=\mathbf{1 / E S}=1)$}

Any fumaroles or thermal features associated with a volcanic system receive a score here. Nisyros' active hydrothermal system is comprised of two distinct aquifers beneath the Lakki plain (Fig. 2) with fluids of both meteoric and magmatic origin (Brombach et al., 2003). The deeper of these is located at more than $900 \mathrm{~m}$ below sea level and is characterised by chloride rich fluids of temperatures higher than $290^{\circ} \mathrm{C}$. The shallower aquifer is located in the southern half of the Lakki plain between sea level and $500 \mathrm{~m}$ below. In this area the fluids within the aquifers have temperatures between $170^{\circ} \mathrm{C}$ and $255^{\circ} \mathrm{C}$ (Chiodini et al., 1993). Chiodini et al. (2002) recorded variations in the chemical composition of fumarolic fluids following the 1996-1998 seismic crisis, and noted an increase in $\mathrm{H}_{2} \mathrm{~S} / \mathrm{CO}_{2}$ ratios and a decrease in $\mathrm{CH}_{4} / \mathrm{CO}_{2}$ ratios between 1997 and 2001. The same authors suggested that this could be due to an increase in temperature and pressure in the upper part of the hydrothermal system and concluded that the potential for hydrothermal explosions on Nisyros was higher than during the 1990's. Caliro et al. (2005) mapped areas of significant $\mathrm{CO}_{2}$ emissions on Nisyros with fluxes of $>80 \mathrm{~g} \mathrm{~m}^{2} /$ day. Coastal hotsprings are also present around Nisyros, with measured temperatures up to $55^{\circ} \mathrm{C}$ (Chiodini et al., 1993; Brombach et al., 2003). Nisyros scores 1 in this category.

\subsection{Hazard factors total score}

The total score for the Hazard factors of the NVEWS system is 9 and 13 for the conservative and extreme score, respectively.

\subsection{NVEWS exposure factors}

\subsubsection{Log10 of Volcano Population Index (VPI30) within $30 \mathrm{~km}(\mathrm{CS}=6.93 / \mathrm{ES}=6.93)$}

The Volcano Population Index is the $\log 10$ of the number of people who could potentially be affected by an eruption, within a $30 \mathrm{~km}$ radius of the volcano. The limit of $30 \mathrm{~km}$ was chosen by the USGS primarily because globally a distance of $30 \mathrm{~km}$ appears to include most proximal populations in all regions. Also, Newhall and Self (1982) state that for a VEI 4-5 eruption a pyroclastic flow has a chance of approximately $5 \%$ of exceeding $30 \mathrm{~km}$ distance from the vent. It is also indicated that the probability of tephra accumulations exceeding $10 \mathrm{~cm}$ at $30 \mathrm{~km}$ downwind are approximately $10 \%$ for a VEI 3 (Newhall and Hoblitt, 2002). The accumulation of several centimetres of tephra has adverse effects on surface transportation, electric power distribution and surface water supplies. To calculate the Nisyros threat score, census data from the 2001 European Union Census was used. The VPI30 score for the local population is therefore the $\log 10$ of 51928 people giving a value of 4.72 .

This total, however, is not representative of the large seasonal population brought to the island by tourism. To get a more accurate number of people that would potentially be affected by a large eruption it is important to look at the annual visitor statistics. Approximately 60000 people visit Nisyros each year (Stiros, 2000; Vougioukalakis and Fytikas, 2005). This seasonal population flux was divided by 365 and the $\log 10$ of this number added to the $\log 10$ population statistics to get the VPI30. In this case the addition of the tourist figures for Nisyros produces a VPI30 of 6.93. This annualaverage population value of course would be an underestimate for the number of people that could be affected by an eruption during peak tourist season, but an over-estimate for the off-season winter months. It must also be noted that this number does not include visitors to the islands of Kos, Tilos or to neighbouring Turkey, all of which are within the $30 \mathrm{~km}$ perimeter. As such both scores are based on an underestimate.

\subsubsection{Approximate population downstream or downslope outside $30 \mathrm{~km}(\mathrm{CS}=0 / \mathrm{ES}=0)$}

The approximate population downstream or downslope is an important consideration only if there is a primary lahar hazard or a significant lava flow hazard (similar to that at $\mathrm{Ki}-$ lauea, Hawaii) that extends farther than $30 \mathrm{~km}$ from vent areas. As previously discussed, there is neither a permanent water source nor potential for lava flows beyond a $30 \mathrm{~km}$ distance on the island, so both the conservative and extreme scores for this category are 0 . 


\subsubsection{Historical fatalities $(\mathrm{CS}=0 / \mathrm{ES}=1)$}

There is no record of any fatalities on the island of Nisyros, and therefore there was a score of 0 for this category in the conservative estimate score. It is important to consider, however that there may have been fatalities that were undocumented. For this reason a score of 1 was given for this category in the extreme estimate score.

\subsubsection{Historical evacuations $(\mathrm{CS}=0 / \mathrm{ES}=1)$}

Whilst there have not been official compulsory evacuations on the island to our knowledge, there has been a substantial decrease in the population due to emigration since the late 1800 's; the timing of which coincided with the last phreatic explosions. There is a measure of uncertainty on the link between volcanic reactivation and mass emigration from Nisyros, as purely economic and societal factors cannot be excluded. Therefore, a score of 0 is awarded for the conservative estimate and a score of 1 for the extreme estimate.

\subsubsection{Local aviation exposure $(\mathrm{CS}=2 / \mathrm{ES}=2)$}

The local aviation exposure is based on the primary threat volcanic activity poses to airports. NVEWS implements a $300 \mathrm{~km}$ radius in its exposure assessment. Several examples in the US have shown that, on average, $75 \%$ of airports affected by volcanic activity are within $300 \mathrm{~km}$ of an erupting volcano (Ewert, 2007). If any type of volcano is within $50 \mathrm{~km}$ of a jet service airport then that volcano will score 1 . If a type 1 volcano, with a generally explosive potential, is within $300 \mathrm{~km}$ of a jet service airport then the score will be 1 . If the volcano is a type 1 and is located within $300 \mathrm{~km}$ of a major international airport then the score will be 2 . We follow here the NVEWS default radius for assessment of aviation exposure i.e. $300 \mathrm{~km}$, but note here that the impact of volcanic eruptions on aviation in Europe is currently under scrutiny following the Eyjafjallajökull volcano in spring 2010 (see also Sect. 7). Nisyros is a type 1 volcano, and there are 30 international and domestic airports within a $300 \mathrm{~km}$ radius (see Fig. 5). The score is therefore 2 for the local aviation exposure.

\subsubsection{Regional aviation exposure $(\mathrm{CS}=5.22 / \mathrm{ES}=5.22)$}

The regional aviation exposure is a $\log 10$ of the daily passenger count on jet aircraft. In this case the numbers of passengers boarding at the international and domestic airports within a $300 \mathrm{~km}$ radius of the volcano were used (see Table 1). The data was gathered from the Ministry of Transport of both Turkey and Greece and allowed for the calculation of a regional aviation exposure score. To calculate this score the yearly total of 61590115 passengers (taken from flight information from the Hellenic Aviation Authority's 2006 statistics and the International Civil Aviation Authority's 2007 statistics) should be divided by 365 , to calculate

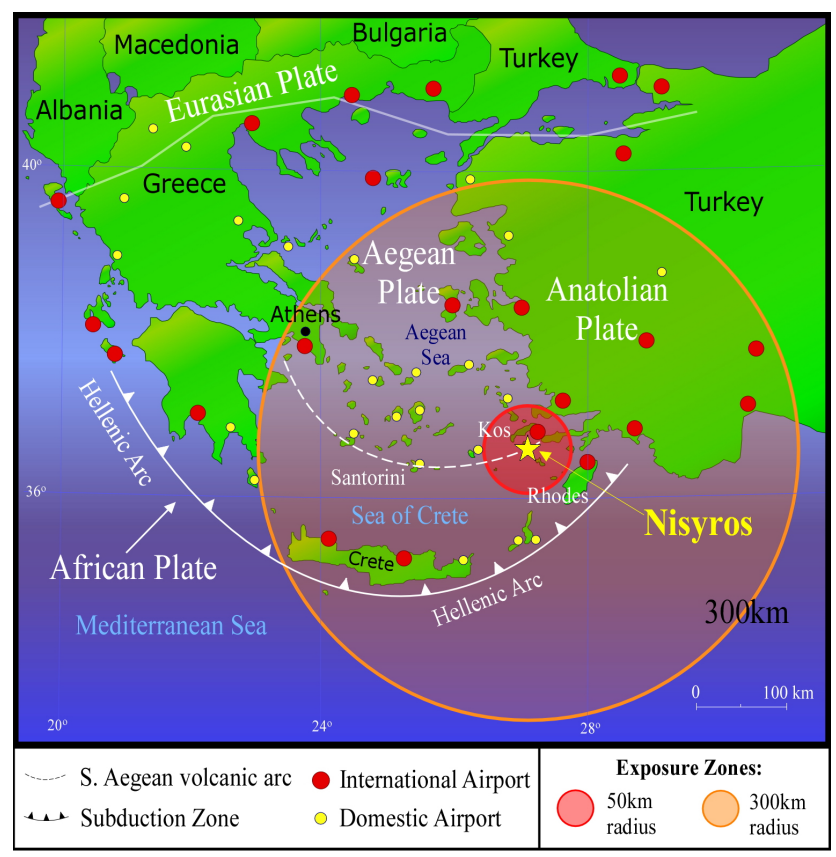

Fig. 5. Possible impact of volcanic eruption on Nisyros on regional air travel as quantified by circular areas with $300 \mathrm{~km}$ and $50 \mathrm{~km}$ radius, respectively. The figure also shows the location of Nisyros in the tectonic context of the Hellenic Arc and location of all international and domestic airports within the proposed impact areas.

the number of passengers flying on a particular day of the year (168 740 passengers/day). The $\log 10$ of this number is then calculated to give the regional aviation exposure score, in this case 5.22. This number does not take into consideration the threat to freight air transport, which is difficult to quantify, or military air movements and therefore is an underestimate.

\subsubsection{Power infrastructure $(\mathrm{CS}=1 / \mathrm{ES}=1)$}

Power generation or transmission and distribution within $30 \mathrm{~km}$ of a flow hazard zone or a general facility in the area typically downwind of the volcano receives a score of 1 . As there is power generation on both Nisyros and Kos, the score here is 1 .

\subsubsection{Transportation infrastructure $(C S=1 / E S=1)$}

This includes consideration for the disruption of port facilities, rail lines and major roads by volcanic activity. The Aegean Sea is home to many major shipping routes, which in the event of an ash fall could be adversely affected. Therefore the score is 1. Damage to transportation infrastructure could also affect evacuation protocols in the event of an eruption. 
Table 1. List of conservative and extreme threat score for analysis criteria for Nisyros, using the guidelines set out in Ewert (2007).

\begin{tabular}{|c|c|c|}
\hline Hazard Factors & $\begin{array}{c}\text { Nisyros } \\
\text { Conservative } \\
\text { Score }\end{array}$ & $\begin{array}{c}\text { Nisyros } \\
\text { Extreme } \\
\text { Score }\end{array}$ \\
\hline Volcano Type & 1 & 1 \\
\hline Maximum Volcano Explosivity Index & 1 & 1 \\
\hline Explosive activity in the past 500 years & 0 & 1 \\
\hline Major Explosive Activity in the Past 5000 years & 1 & 1 \\
\hline Eruption Recurrence & 0 & 1 \\
\hline Holocene Pyroclastic Flows & 1 & 1 \\
\hline Holocene Lava Flows & 0 & 1 \\
\hline Holocene Lahars & 0 & 0 \\
\hline Holocene Tsunami & 0 & 1 \\
\hline Hydrothermal Explosion Potential & 1 & 1 \\
\hline Sector Collapse Potential & 1 & 1 \\
\hline Primary Lahar Source & 0 & 0 \\
\hline Observed Seismic Activity & 1 & 1 \\
\hline Observed Ground Deformation & 1 & 1 \\
\hline Observed Fumarolic or Magmatic Degassing & 1 & 1 \\
\hline Total Hazard Factors & 9 & 13 \\
\hline \multicolumn{3}{|l|}{ Exposure Factors } \\
\hline Log10 of Volcano Population Index (VPI) within $30 \mathrm{~km}$ & 6.93 & 6.93 \\
\hline Approximate Population Downstream or Downslope Outside $30 \mathrm{~km}$ & 0 & 0 \\
\hline Historical Fatalities & 0 & 1 \\
\hline Historical Evacuations & 0 & 1 \\
\hline Local Aviation Exposure & 2 & 2 \\
\hline Regional Aviation Exposure & 5.22 & 5.22 \\
\hline Power Infrastructure & 1 & 1 \\
\hline Transportation Infrastructure & 1 & 1 \\
\hline Major development in Sensitive Areas & 1 & 1 \\
\hline Volcano is a Significant Part of a Populated Island & 1 & 1 \\
\hline Total Exposure Factors & 18.15 & 20.15 \\
\hline \multicolumn{3}{|l|}{ Sum of all hazard factors $\cdot$ sum of exposure } \\
\hline factors $=$ Relative threat ranking & 163.35 & 261.95 \\
\hline
\end{tabular}

\subsubsection{Major development/sensitive areas $(\mathrm{CS}=1 / \mathrm{ES}=1)$}

This applies to areas that are either in economically or symbolically important places, or if the area has been developed into a national park. Nisyros is a popular holiday destination, with approximately 60000 people visiting each year red (Vougioukalakis and Fytikas, 2005), and therefore a score of 1 is given.

\subsubsection{The Volcano is a significant part of a populated island $(\mathrm{CS}=1 / \mathrm{ES}=1)$}

It can be difficult to mitigate volcanic hazards on small islands. This is because if the volcano makes up a significant part of the island, evacuation can be very difficult. As mentioned previously, the disruption of local water transport could adversely affect evacuation protocols. Nisyros is an entirely volcanic island and therefore scores 1 for this category.

\subsection{Exposure factors total score}

The total score for the exposure factors of the NVEWS system was therefore 18.15 and 20.15 for the conservative and extreme scores, respectively.

\section{Threat scores and monitoring gap analysis}

\subsection{Resultant NVEWS threat scores}

A summary of conservative and extreme scores for the individual categories are shown in Table 1 .

The scores generated by assessing the volcanic threat that Nisyros poses are more useful when seen in context with other volcanoes that have been assessed using the same scheme. Ewert et al. (2005) used the scores for the overall threat score and the aviation threat score to divide the US volcanoes into five threat groups from "Very High" to 
Table 2. Threat score for Nisyros in relation to 18 volcanoes that make up the "Very High Threat" group in the United States. Following Ewert (2007) the volcanoes that are currently displaying unrest or that are already erupting are shown in the "Status" section. The scores for Nisyros are displayed for comparison.

\begin{tabular}{lcccccc}
\hline Volcano & State & $\begin{array}{c}\text { Aviation } \\
\text {-Threat }\end{array}$ & Threat & $\begin{array}{c}\text { Required } \\
\text { Monitoring }\end{array}$ & $\begin{array}{c}\text { Current } \\
\text { Monitoring }\end{array}$ & Status \\
\hline Kilauea & HI & 46 & 324 & 4 & 4 & Erupting \\
Mt. St. Helens & WA & 56 & 267 & 4 & 4 & Erupting \\
Nisyros (Extreme) & - & 41.6 & 262 & 4 & 1 & Unrest \\
Rainier & WA & 35 & 244 & 4 & 2 & \\
Hood & OR & 26 & 213 & 4 & 2 & \\
Shasta & CA & 37 & 210 & 4 & 2 & \\
South Sister & OR & 26 & 194 & 4 & 2 & \\
Lassen Volcanic Center & CA & 31 & 186 & 4 & 2 & Unrest \\
Mauna Loa & HI & 4 & 170 & 4 & 3 & Unrest \\
Redoubt & AK & 44 & 164 & 4 & 3 & \\
Nisyros (Conservative) & - & 31.32 & 163 & 4 & 1 & \\
Crater Lake & OR & 35 & 161 & 4 & 1 & \\
Baker & WA & 14 & 156 & 4 & 2 & \\
Glacier Peak & WA & 35 & 155 & 4 & 1 & \\
Makushin & AK & 34 & 152 & 4 & 3 & \\
Spurr & AK & 44 & 130 & 4 & 3 & Unrest \\
Long Valley Caldera & CA & 29 & 128 & 4 & 4 & 0 \\
Newberry Volcano & OR & 28 & 126 & 4 & 2 & 2 \\
Augustine & AK & 44 & 123 & 4 & 3 & 1 \\
\hline
\end{tabular}

"Very Low". Both of the scores attained by Nisyros (163.35 and 261.95) place the volcano in the "Very High Threat" category. For illustration, Table 2 shows the rank that these scores would give Nisyros among the 18 US volcanoes in this category.

\subsection{Monitoring gap analysis}

The monitoring gap analysis is the method developed to determine the difference between the current level of monitoring at a volcano and the level called for by its threat score (Ewert, 2005). This analysis is intended to be a tool for prioritising monitoring targets before the onset of unrest or eruption (Ewert, 2005). To perform this analysis a current monitoring level for the volcano must be assessed. This is dependent on the monitoring capabilities in the following fields; seismic, deformation, gas, hydrologic, and remote sensing. These techniques are rated using a score from 0 to 4 , where 0 is for no real-time ground-based monitoring and 4 is for well monitored in real time. A generous assessment of Nisyros' monitoring capabilities would place it as Level 1, or minimal monitoring, based on the availability of a baseline inventory of Landsat-class satellite images and basic seismic monitoring at Emborios observatory on the caldera rim. Nisyros does meet the criteria that if an eruption was to occur it would be detected. The NVEWS scheme suggests that US volcanoes that fall into the "very high threat" category should have Level 4 monitoring. This level of monitoring involves monitoring in real time, routine deformation surveys, frequent gas measurements and a suite of remote sensing analyses including high resolution thermal infra-red.

\section{Discussion}

\subsection{The threat score in a US American context}

Using NVEWS as a tool to assess Nisyros' volcanic threat in conjunction with the monitoring gap analysis, it emerges that this rather unassuming island is currently underestimated as posing a threat. Table 2 shows that the conservative score for Nisyros falls between that for Redoubt and Crater Lake, whereas the extreme score falls between Mt. St. Helens and Mt. Rainier. Three of these are historically active (Sorenson and Gersmehl, 1980; Trople, 2004; Simkin and Siebert, 1994), and all four of them are large volcanic centres. In comparison, the only historical activity recorded on Nisyros is the phreatic eruptions between 1871 and 1873 and in 1888 . Looking solely at the hazard factors (the threat of the physical hazards from the volcano), this volcano does not fall into the "Very High Threat category" defined by NVEWS. Instead it is the exposure factors such as the Volcano Population Index and the Regional Aviation Score that cause the high threat score to be produced. 


\subsection{The threat score in a European context}

\subsubsection{Comparison with other Southern European volcanoes}

In order to assess Nisyros's threat score in a European context, it is worth comparing the score to other European volcanoes. In the absence of a similar study to the best of our knowledge, we consult Yokoyama et al. (1984) who suggested grouping volcanoes by continent rather than attempting to create a worldwide ranking. This may mean that to better understand the implication of the threat score it should be compared to the scores for other volcanoes in the region such as Santorini, Vesuvius, Campi Flegrei and Etna. These volcanoes in addition to Nisyros were previously identified in the Yokoyama et al. (1984) scheme as fitting the 'high risk' criteria. It would be of great interest to see how these other volcanoes compare in terms of their NVEWS threat level to our findings for Nisyros. This may provide a better context for our results than by comparison with US volcanoes. The 1996-1998 volcano-seismic crisis at Nisyros is not dissimilar to the 1982-1984 crisis at the Campi Flegrei and likely also similar to other caldera unrest episodes in the Mediterranean region and elsewhere: significant ground uplift is detected, yet, not accompanied or immediately followed by eruption. For example, the net ground uplift of more than $2.5 \mathrm{~m}$ during both the 1969-1972 and 1982-1984 at Campi Flegrei is interpreted to result from pressurisation of either a purely magmatic, a purely hydrothermal or a hybrid source (see Gottsmann and Battaglia, 2008 for a recent review). These observations compare with ground uplift of more than $7 \mathrm{~m}$ prior to the 1538 Monte Nuovo eruption at the Campi Flegrei (Dvorak and Gaspirani, 1991). The implication of these observations is that unrest periods remain poorly understood and causative sources enigmatic.

\subsubsection{Population and aviation exposure}

The Volcano Population Index at $30 \mathrm{~km}$ distance for Nisyros is higher than any US volcano assessed by the NVEWS scheme. Steamboat has the highest score in the US at 5.41 (Ewert et al., 2005), whereas Nisyros gives a score of 6.93. The high population density in the immediate vicinity of Nisyros has implications in its own right in terms of the potential impact on local population and infrastructure. However, due to the high population density in Europe in general many more people could be affected by an eruption on Nisyros. The air traffic disruption by the eruption of Eyjafjallajökull volcano in spring 2010 showed the vulnerability of European society to volcanic hazards on an unprecedented scale. With a Regional Aviation Score for Nisyros higher than for any US volcano (a score of 5.15 for Steamboat being the highest) and the minimum estimated cost of US $\$ 2.5 \mathrm{Bn}$ to the global aviation industry at large for the Eyjafjallajökull eruption (European Commission Press Re- lease 27 April 2010), the impact on air traffic may be among the most severe scenarios of volcano reactivation on Nisyros, with implications on regional and possibly continental scale. Whether or not an area of $300 \mathrm{~km}$ radius around a volcano, as currently defined by the NVEWS scheme as a potential exposure zone with possible impact on air traffic, is appropriate to reflect the nature of European air traffic and the distribution density of airports in Europe is an open question. One anticipates that a post-mortem analysis of the recent Icelandic eruption and its impact on air traffic in Europe will provide advances in this respect in an European context.

\subsubsection{Adequate monitoring level}

Using the threat score to analyse the monitoring gap on Nisyros shows that there is indeed a substantial difference between what capabilities currently exist on Nisyros compared to what would be required by the NVEWS recommendations if this volcano was in the US. Even conservatively, Nisyros volcano appears inadequately monitored and we suggest this situation be addressed to obtain a realistic understanding of base level activity on the island. It is perhaps realistic to expect a level of monitoring appropriate for the level of threat from a volcano. In this context it is clear that there is a need for a higher monitoring level then is currently in place on Nisyros. This would allow for the isolation of "anomalous" activity periods, such as the volcano-seismic crisis in the 1990's, and assess their importance.

\section{Conclusions}

Whilst it may be true that the exposure factors on Nisyros may cause a bias towards a higher comparable threat score then expected, our analysis provides a comprehensive step towards understanding the volcanic hazards from this volcanic island in a European context, not at least because of the recently exposed severe vulnerability of European society to volcanic eruptions as demonstrated by the case of the Eyjafjallajökull volcano. The derived threat scores of 163 and 262 bracket the range of possible scores for Nisyros as any permutation of the extreme and conservative scores for both hazard and exposure factors is feasible.

From the analysis of volcanic threat presented in this paper it emerges that, coupled with an increase in monitoring capability, a sensible course of action for the local and regional authorities would be to develop a volcanic hazard specific response protocol. This would increase the level of preparedness locally and regionally in the event of re-awakening of volcanic activity and therefore significantly reduce risk associated with volcanic activity. Our analysis could represent a first step towards a comprehensive risk analysis including a combination of probabilistic volcanic hazard assessment and eruption forecasting with cost-benefit analysis (Marzocchi and Woo, 2007). 
Acknowledgements. This paper builds on work towards a M.Sc. degree by A. Winson and a Ph.D. degree by H. Kinvig at the University of Bristol, and both authors have contributed equally to this publication. All authors contributed to the analysis, the evaluation of results and the writing of the manuscript. A Royal Society University Research Fellowship and research and studentship grants by the Natural Environmental Research Council supported the work. JG also acknowledges support by BRISK (University of Bristol's Research Centre for Environmental Risk). Staff and students of the 2008 Environmental Geosciences field school are thanked for help with field data collection. E. Partington and A. Geyer assisted during the initial stages of the analysis. We thank A. Duncan and an anonymous reviewer for their valuable comments, which led to significant improvements of this work.

Edited by: J. Marti

Reviewed by: A. Duncan and another anonymous referee

\section{References}

Aksu, A. E., Jenner, G., Hiscott, R. N., and Isler, E.: Occurrence, stratigraphy and geochemistry of Late Quaternary tephra layers in the Aegean Sea and the Marmara Sea, Mar. Geol., 252, 174192, 2008.

Allen, S.: Reconstruction of a major caldera-forming eruption from pyroclastic deposit characteristics: Kos Plateau Tuff, eastern Aegean Sea, J. Volcanol. Geoth. Res., 105(1-2), 141-162, 2001.

Barberi, F., Navarro, J., Rosi, M., Santacroce, R., and Sbrana, A.: Explosive interaction of magma with ground water: insights from xenoliths and geothermal drillings, Rendiconti della Società Italiana di Mineralogia e Petrologia, 43, 901-926, 1988.

Brombach, T., Caliro, S., Chiodini, G., Fiebig, J., Hunziker, J., and Raco, B.: Geochemical evidence for mixing of magmatic fluids with seawater, Nisyros hydrothermal system, Greece, B. Volcanol., 65, 505-516, 2003.

Caliro, S., Chiodini, G., Galluzzo, D., Granieri, D., La Rocca, M., Saccorotti, G., and Ventura, G.: Recent activity of Nisyros volcano, Greece) inferred from structural, geochemical and seismological data, B. Volcanol. 67(4), 358-369, 2005.

Chiodini, G., Cioni, R., Leonis, C., Marini, L., and Raco, B.: Fluid geochemistry of Nisyros island, Dodecanese, Greece, J. Volcanol. Geoth. Res., 56(1-2), 95-112, 1993.

Dvorak, J. and Gasparini, P.: History of earthquakes and vertical ground movement in Campi Flegrei caldera, Southern Italy: comparison of precursory events to the A.D. 1538 eruption of Monte Nuovo and of activity since 1968, J. Volcanol. Geoth. Res., 48, 77-92, 1991.

Ewert, J.: System for Ranking Relative Threats of US Volcanoes, Natural Hazards Review 8, 112-124, 2007.

Ewert, J., Guffanti, M., and Murray, T.: An Assessment of Volcanic Threat and Monitoring Capabilities in the United States - Framework for a National Volcanic Early Warning System, NVEWS), US Geological Survey Open-File Report 1164, 1-62, 2005.

Gottsmann, J. and Battaglia, M.: Deciphering causes of unrest at collapse calderas: Recent advances and future challenges of joint gravimetric and ground deformation studies, in: Caldera volcanism: Analysis, modelling and response, edited by: Gottsmann, J. and Marti, J., Developments in Volcanology, Elsevier, 10, 417446, 2008.
Gottsmann, J., Carniel, R., Coppo, N., Wooller, L., Hautmann, S., and Rymer, H.: Oscillations in hydrothermal systems as a source of periodic unrest at caldera volcanoes: Multiparameter insights from Nisyros, Greece, Geophys. Res. Lett., 34, L07307, doi:10.1029/2007GL029594, 2007.

Gottsmann, J., Rymer, H., and Wooller, L. K.: On the interpretation of gravity variations in the presence of active hydrothermal systems: Insights from the Nisyros Caldera, Greece, Geophys. Res., Lett., 32, 7, doi:10.1029/2005GL024061, 2005.

Hardiman, J.: Deep sea tephra from Nisyros Island, eastern Aegean Sea, Greece, Special Publication of the Geological Society London: Volcanoes in the Quaternary, 161, 69-88, 1999.

Innocenti, F., Manetti, P., Peccerillo, A., and Poli, G.: South Aegean volcanic arc: Geochemical variations and geotectonic implications, B. Volcanol., 44(3), 377-391, 1981.

Innocenti, F., Manetti, P., Peccerillo, A., and Poli, G.: South Aegean volcanic arc: Geochemical variations and geotectonic implications, B. Volcanol., 44(3), 377-391, 1981.

Keller, J.: The major volcanic events in recent eastern Mediterranean volcanism and their bearing on the problem of Santorini ash layers, Actu Internat. Sci. Congr. on the Volcano of Thera, 152-167, 1971.

Keller, J., Rehren, T., and Stadlbauer, E.: Explosive Volcanism in the Hellenic Arc: a Summary and Review, in: Thera and the Aegean World III: Proceedings of the Third International Congress, Santorini, Greece, 3-9 September 1989, Thera Foundation, p. 13, 1990.

Lagios, E., Sakkas, V., Parcharidis, I., and Dietrich, V.: Ground deformation of Nisyros Volcano, Greece) for the period 19952002: Results from DInSAR and DGPS observations, B. Volcanol., 68(2), 201-214, 2005.

Limburg, E. and Varekamp, J.: Young pumice deposits on Nisyros, Greece, B. Volcanol., 54(1), 68-77, 1991.

Lopez, D. and Williams, S.: Catastrophic volcanic collapse: relation to hydrothermal processes, Science, 260(5115), 1794-1796, 1993.

Margari, V., Pyle, D., Bryant, C., and Gibbard, P.: Mediterranean tephra stratigraphy revisited: results from a long terrestrial sequence on Lesvos Island, Greece, J. Volcanol. Geoth. Res., 163(1-4), 34-54, 2007.

Marini, L., Principe, C., Chiodini, G., Cioni, R., Fytikas, M., and Marinelli, G.: Hydrothermal eruptions of Nisyros, Dodecanese, Greece. Past events and present hazard, J. Volcanol. Geotherm. Res., 56, 71-94, 1993.

Marzocchi, W. and Woo, G.: Principles of volcanic risk metrics: Theory and the case study of Mount Vesuvius and Campi Flegrei, Italy, J. Geophys. Res., 114(1), B03213, doi:10.1029/2008JB005908, 2009.

Newhall, C. and Hoblitt, R.: Constructing event trees for volcanic crises, B. Volcanol., 64(1), 3-20, 2002.

Newhall, C. and Self, S.: The volcanic explosivity index/VEI/-An estimate of explosive magnitude for historical volcanism, J. Geophys. Res., 87(C2), 12311238, doi:10.1029/JC087iC02p01231, 1982.

Papadopoulos, G., Sachpazi, M., Panopoulou, G., and Stavrakakis, G.: The volcanoseismic crisis of 1996-97 in Nisyros, SE Aegean Sea, Greece, Terra Nova, 10(3), 151-154, 1998.

Papazachos, B., Dimitriadis, S., Panagiotopoulos, D., Papazachos, C., and Papadimitriou, E.: Deep structure and active tectonics 
of the Southern Aegean volcanic arc, The south Aegean active volcanic arc: present knowledge and future perspectives, 47-64, 2005.

Pe-Piper, G. and Piper, D.: The South Aegean active volcanic arc: relationships between magniatism and tectonics, The South Aegean Active Volcanic Arc: Present Knowledge and Future Perspectives, 2005.

Principe, C. and Marini, L.: Reaction path modelling of argillic alteration (AA) and advanced argillic alteration, AAA): Consequences for debris avalanches induced by flank collapse and hydrothermal eruptions, The Geology, Geochemistry and Evolution of Nisyros Volcano, Greece), in: Implications for the Volcanic Hazards, Mémoires de Géologie, Lausanne, 164-179, 2005.

Pyle, D. and Margari, V.: Reply: Correlation of a widespread Pleistocene tephra marker from the Nisyros-Yali volcanic complex, Greece, J. Volcanol. Geoth. Res., 181, 3-4, 251-254, 2009.

Sachpazi, M., Kontoes, C., Voulgaris, N., Laigle, M., Vougioukalakis, G., Sikioti, O., Stavrakakis, G., Baskoutas, J., Kalogeras, J., and Lepine, J.: Seismological and SAR signature of unrest at Nisyros caldera, Greece, J. Volcanol. Geoth. Res., 116(1-2), 19-33, 2002.

Simkin, T. and Siebert, L.: Volcanoes of the world, Arizona, Geoscience Press, Tucson, Arizona, 349 pp., 1994.

Smith, P., York, D., Chen, Y., and Evensen, N.: Single crystal 40Ar39Ar dating of a Late Quaternary paroxysm on Kos, Greece: Concordance of terrestrial and marine ages, Geophys. Res. Lett., 23, 21, 3047-3050, 1996.

Sorensen, J. and Gersmehl, P.: Volcanic hazard warning system: Persistence and transferability, Environ. Manage., 4(2), 125-136, 1980.

St. Seymour, K. and Vlassopoulos, D.: The potential for future explosive volcanism associated with dome growth at Nisyros, Aegean volcanic arc, Greece, J. Volcanol. Geoth. Res., 37, 351364, 2008.

Stiros, S.: Fault pattern of Nisyros Island volcano (Aegean Sea, Greece): structural, coastal and archaeological evidence, in: The Archaeology of Geological Catastrophes, Geological Society London Special Publications, 171(1), 385-397, 2000.

Tibaldi, A., Pasquarè, F., Papanikolaou, D., and Nomikou, P.: Discovery of a huge sector collapse at the Nisyros volcano, Greece, by on-land and offshore geological-structural data, J. Volcanol. Geoth. Res., 177(2), 485-499, 2008.

Trople, T.: Volcanic Hazards Vulnerability Assessment of the Enumclaw-Buckley, Washington Community, Department of Resource Analysis, Saint Mary's University of Minnesota, available at: http://www.gis.smumn.edu/GradProjects/TTrople.pdf (last access: 1 June 2010), 20 pp., 2004.
Vanderkluysen, L., Volentik, A., Principe, C., Hunziker, J., and J. H.: Nisyros volcanic evolution: the growth of a stratocone, in: The Geology, Geochemistry and Evolution of Nisyros Volcano, Greece. Implications for the Volcanic Hazards, Mémoires de Géologie, Lausanne, 100-106, 2005.

Vinci, A.: A new ash-layer "Nisyros layer" in the Aegean Sea sediments, Bollettino di oceanologia teorica ed applicata, 341-342, 1983.

Vinci, A.: Distribution and chemical composition of tephra layers from eastern Mediterranean abyssal sediments, Mar. Geol., 64(1-2), 143-155, 1985.

Volentik, A., Vanderkluysen, L., Principe, C., and Hunziker, J.: Stratigraphy of Nisyros Volcano, Greece), in: The Geology, Geochemistry and Evolution of Nisyros Volcano, Greece. Implications for the Volcanic Hazards, Mémoires de Géologie, Lausanne, 26-66, 2005.

Vougioukalakis, G.: Blue Volcanoes: Nisyros, Published by Nisyros Regional Council, Nisyros, Greece, 1998.

Vougioukalakis, G. and Fytikas, M.: Volcanic hazards in the Aegean area, relative risk evaluation, monitoring and present state of the active volcanic centers, The South Aegean Active Volcanic Arc: Present Knowledge and Future Perspectives, 2005.

Yokoyama, I., Tilling, R., and Scarpa, R.: International mobile early-warning systems for volcanic eruptions and related seismic activities, UNESCO (Paris), EP/2106-8201 (2286), 102 pp., 1984.

\section{Consulted webpages}

Greek Ministry of Transport and Communications, Civil Aviation; http://www.hcaa.gr/home/index.asp

International Civil Aviation Organisation; http://www.icao.int/icao/en/m_links.html

Republic of Turkey, Prime Ministry, Turkish Statistical Institute (Turkstat); http://www.die.gov.tr/ENGLISH/index.html

Republic of Turkey, Ministry of Transport and Communications, Director General of Civil Aviation; http://www.shgm.gov.tr/indexeng2.html

General Secertariat of the National Statistical Survey of Greece; http://www.statistics.gr/Main_eng.asp

European Commission Press Room; http://ec.europa.eu/commission_2010-2014/kallas/headlines/ news/2010/04/doc/information_note_volcano_crisis.pdf 